\title{
PENGARUH MODEL PEMBELAJARAN BERDASARKANMASALAH (PROBLEM BASED LEARNING)TERHADAP HASIL BELAJAR SISWA PADA MATERI POKOK BESARAN DAN SATUAN DI KELAS X SEMESTER I SMA SWASTA BUDI AGUNG MEDAN T.P. 2014/2015
}

\author{
Amir Hamzah Lubis dan Pintor Simamora \\ Jurusan Fisika FMIPA Universitas Negeri Medan \\ Jalan Willem Iskandar Pasar V Medan, Sumatera Utara \\ Amirhmhz09@gmail.com
}

\begin{abstract}
ABSTRAK
Penelitian ini bertujuan untuk mengetahui pengaruh model pembelajaran berdasarkan masalah (problem based learning) dan modelpembelajaran konvensional terhadap hasil belajar dan aktivitas siswa pada materi Besaran, Satuan dan Pengukuran. Jenis penelitian ini adalah quasi eksperimen. Populasi dalam penelitian ini adalah seluruh siswa kelas $\mathrm{X}$ SMA Swasta Budi Agung Medan yang terdiri dari 6 kelas, yang seluruh siswanya berjumlah 250 orang siswa. Sampeldalanm penelitian ini diambil 2 kelas yang ditentukan secara cluster rondom sampling yaitu kelas X-1 yang terdiri dari 40 orang sebagai kelas eksperimen dan X-2 yang terdiri dari 40 orang siswa sebagai kelas kontrol. Instrumen yang digunakan ada 2 jenis, yaitu : 1 . Tes hjasil belajar dalam bentuk pilihan berganda sebanyak 20 soal dengan lima pilihan jawaban yang sebelumnya telah dilakukan uji persyaratan tes, 2 . Lembar observasi aktivitas siswa demgan menggunakan model pembelajaran berdasarkan masalah. Dari data penelitian diperoleh nilai rata-rata pretes kelas eksperimen adalah 52,5 dengan standar deviasi 13,0 dan kelas kontrol adalah 53,3 dengan standar deviasi 13,6. Setelah diberikan perlakuan yang berbeda, kelas eksperimen dengan modelpembelajaran berdasarkan masalah dan kelas kontrol dengan model pembelajaran konvensional, diperoleh nilai postes dengan hasil rata-rata kelas eksperimen 73,6 dan standar deviasi 10,3 dan kelas kontrol 60,8 dan standar deviasi 12,9. Hasil uji $t$ menunjukkan ada pengaruh yang signifikan terhadap hasil belajar siswa menggunakan model pembelajaran berdasarkan masalah terhadap hasil siswa pada materi pokok Besaran dan Satuan di kelas X Semester I SMA Swasta Budi Agung Medan T.P $2014 / 2015$.
\end{abstract}

Kata Kunci : pembelajaran berdasarkan masalah, hasil belajar,aktivitas.

\section{PENDAHUALUAN}

Pendidikan merupakan suatu upaya untuk meningkatkan kualitas setiap individu secara langsung atau tidak langsung dipersiapkan untuk menopang dan mengikuti laju perkembangan ilmu pengetahuan dan teknologi dalam rangka mensukseskan pembangunan sejalan dengan tuntutan kebutuhan.

Guru fisika masih menggunakan proses pembelajaran 
yang berpusat pada guru karena guru jarang melibatkan siswa dalam pembelajaran dan hanya menekankan siswa untuk menghapal rumus-rumus-rumus tanpa menekankan konsep dan menerapkan fisika, sehingga kemampuan siswa dalam memahami dan menerapkan konsep fisika kurang yang menyebabkan nilai hasil belajar juga rendah. Pembelajaran yang disampaikan sangat monoton, sehingga kebanyakan aktivitas siswa dalam memecahkan suatu masalah hanya dengan menghapal rumus yang ada di dalam bukunya tanpa diaanalkisa terlebih dahulu. Aktivitas seperti ini kegiatan yang menyebabkan sikap ilmiah siswa dalam mengikuti pembelajaran kurang berkembang dengan baik.

Pembelajaran berdasaran masalah menuntut siswa untuk melakukan pemecahan masalahmasalah yang disajikan dengan cara menggali informasi sebanyakbanyaknya, kemuadian menganalisis dan mencari solusi dari permasalahan yang ada. Pembelajaran berdasarkan masakah mengorientasikian siswa kepada masalah, multi disiplin, menuntut kerjasama dalam penelitian, dan menyajikan hasil karya.

Model

pembelajaran

berdasarkan masalah adalah salah satu upaya solusinya, model pembelajaran inin dirancang dengan tujuan untuk membantu siswa mengembangjkan kemampuan berpikir dan mengembangkan kemempuan dalam memecahkan masalah kehidupan sehari-hari, sehingga siswa lebih paham terhadap konsep fisika yang berkaitan dengan kehidupan sehari-hari.

\section{METODE PENELITIAN}

Penelitian ini termasuk quasi experiment. Penelitian ini dilaksanakan di SMA Swasta Budi Agung Medan. Waktu penelitian dilakukan Semester I T.P.2014/ 2015.

Populasi dalam penelitian ini adalah seluruh kelas X Semester II SMA Swasta Budi Agung Medan, yang terdiri dari 6 kelas. Sampel dalam penelitian ini terdiri dari dua kelas yaitu kelas X-1 sebayak 40 orang sebagai kelas eksperimen dan kelas X-2 sebanyak 40 orang sebagai kelas kontrol yang diambil dengan teknik cluster random sampling.

Instrumen yang digunakan adalah tes hasil belajar siswa dan lember observasi aktivitas siswa. Tes hasil belajar berjumlah 20 soal dalam bentuk pilihan berganda dengan lima pilihan (option) yang terlebih dahulu sudah di validasi isi oleh para ahli. Tes ini diberikan sebanyak 2 kali yaitu pada saat pretes dan postes. Lembar observasi digunakan untuk mengamati aktivitas belajar siswa selama pelaksanaan pembelajaran. Observasi dilakukan oleh observer yang berjumlah dua orang.

Penelitian ini melibatkan dua kelas yang diberi perlakuan yang berbeda. Untuk mengetahui hasil belajar fisika siswa dilakukan dengan memberikan tes pada kedua kelas sebelum dan sesudah diberikan perlakuan. Desain penelitian dapat dilihat pada Tabel 1.

Tabel.1 Two Group Pretest dan Postest

\begin{tabular}{|l|l|l|l|}
\hline Kelas & $\begin{array}{l}\text { Pre } \\
\text { Tes }\end{array}$ & Perlakuan & $\begin{array}{l}\text { Pos } \\
\text { Tes }\end{array}$ \\
\hline Eksperimen & $\mathrm{T}_{1}$ & $\mathrm{X}$ & $\mathrm{T}_{2}$ \\
\hline Kontrol & $\mathrm{T}_{1}$ & $\mathrm{Y}$ & $\mathrm{T}_{2}$ \\
\hline
\end{tabular}


Keterangan :

$\mathrm{T}_{1}$ : Tes kemampuan awal (pretes) untuk kelas eksperimen dan kelas kontrol.

$\mathrm{T}_{2}$ : Tes kemampuan akhir (postes) untuk kelas eksperimen dan kelas kontrol.

$\mathrm{X}_{1}$ : Perlakuan pembelajaran dengan model pembelajaran berbasis masalah

$\mathrm{Y}$ : Perlakuan pembelajaran dengan model pembelajaran konvensional.

Hasil pretes yang diperoleh dilakukan uji prasyarat yaitu uji normalitas untuk mengetahui apakah data berdistribusi normal atau tidak. Kemudian dilakukan uji homogen untuk mengetahui apakah data bersifat homogen atau tidak. Setelah data berdistribusi normal dan juga homogen, maka dilakukan Uji t dua pihak (uji kemampuan awal/pretes) yang digunakan untuk mengetahui kesamaan kemampuan awal siswa pada kedua kelompok sampel.(Sudjana, 2005). Selanjutnya apabila kedua kelas sampel diketahui mempunyai kemampuan awal yang sama maka kedua sampel diberikan perlakuan yang berbeda. Kelas eksperimen diberikan perlakuan dengan model pembelajaran berbasis masalah dan kelas kontrol diberikan perlakuan dengan menggunaka model pembelajaran konvensional. Setelah diberikan perlakuan maka selanjutnya adalah kedua kelas diberikan postes. Untuk mengolah data pada postes sama seperti pada pretes dilakukan uji prasyarat yaitu uji normalitas dan uji homogen. Setelah data berdistribusi normal dan juga homogen maka dilakukaan uji t (uji kemampuan akhir/postes) yang digunakan untuk mengetahui apakah hasil belajar siswa dengan menerapkan model pembelajaran berdasarkan masalah lebih baik dibandingkan dengan model pembelajaran konvensional pada materi pokok besaran dan satuan.

\section{HASIL DAN PEMBAHASAN}

\section{Hasil Penelitian}

Data pretes kelas eksperimen dan kelas kontrol dapat dilihat pada Gambar 1.

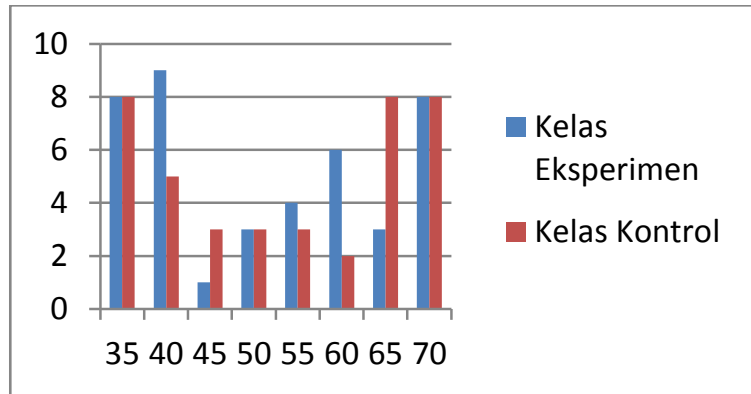

Gambar 1. Data Nilai Pretes Kelas Eksperimen dan Kelas Kontrol

Hasil uji normalitas yang diperoleh dapat dilihat pada Tabel 1.

Tabel 1. Uji normalitas Data Pretes

\begin{tabular}{|l|l|l|l|}
\hline \multirow{2}{*}{ Kelas } & \multicolumn{2}{|l|}{ Data Pretes } & \multirow{2}{*}{ Kesimpulan } \\
\cline { 2 - 3 } & Lhitung & Ltabel & \\
\hline Eksperimen & 0,1190 & 0,1401 & Normal \\
\hline Kontrol & 0,1365 & 0,1401 & Normal \\
\hline
\end{tabular}

Berdasarkan Tabel 1 diperoleh bahwa data pretes kedua kelas berdostribusi normal. Pengujian hipotesis dilakukan dengan uji $\mathrm{F}$. Hasil Uji homogenitas data yang diperoleh dapat dilihat pada Tabel 2 .

Tabel 2. Ringkasan Hasil Uji Homogenitas Data Pretes

\begin{tabular}{|l|l|l|l|l|}
\hline Data & Varians & Fhitung & Ftabel & Kesimpulan \\
\hline Eksperimen & 169,2 & & & Homogen \\
\cline { 1 - 2 } Kontrol & 185,3 & 1,095 & 1,705 & \\
\hline
\end{tabular}

Berdasarkan Tabel 2 nilai $\mathrm{F}_{\text {hitung }}$ $<\mathrm{F}_{\text {tabel }}$ yang berarti bahwa sampel yang digunakan dalam penelitian ini dinyatakan homogen atau dapat mewakili seluruh populasi yang ada. Hasil uji beda kemampuan awal dapat dilihat pada Tabel 3. 
Tabel 3. Ringkasan perhitungan Uji t Pretes

\begin{tabular}{|l|l|l|l|l|}
\hline \multicolumn{1}{|c|}{ Data } & $\begin{array}{c}\text { Rata- } \\
\text { rata }\end{array}$ & thitung & t $_{\text {tabel }}$ & \multicolumn{1}{|c|}{ Kesimpulan } \\
\hline Eksperimen & 52,52 & Kemampuan \\
\cline { 1 - 2 } & 53,3 & 0,268 & 1,997 & $\begin{array}{l}\text { Kemal siswa } \\
\text { Kowal sama } \\
\text { Kona }\end{array}$ \\
\hline
\end{tabular}

Data Postes Kelas Eksperimen dan Kelas Kontrol

Hasil yang diperoleh adalah, nilai rata-rata postes kelas ekperimen setelah diterapkan model pembelajaran berdasarkan masalah sebesar 73,6 dan dikelaskontrol diperoleh dengan nilai rata-rata 60,8. Data postes dapat dilihat pada Gambar 2.

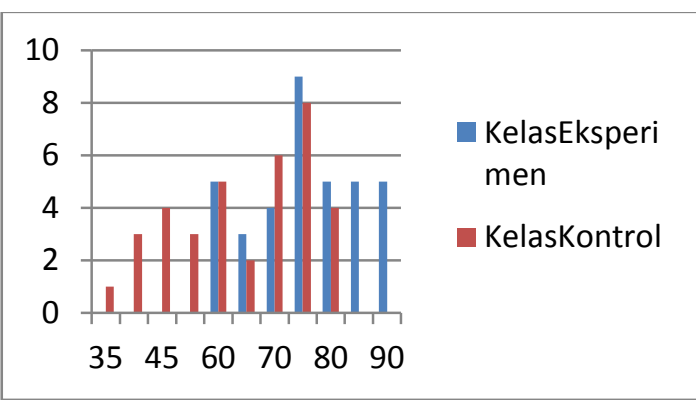

Gambar 2. Diagram Batang Data Postes

Hasil uji normalitas tang diperoleh dapat dilihat pada Tabel 4 .

Tabel 4. Uji Normalitas Data Postes

\begin{tabular}{|l|l|l|l|}
\hline \multirow{2}{*}{ Kelas } & \multicolumn{2}{|l|}{ Data Pretes } & \multirow{2}{*}{ Kesimpulan } \\
\cline { 2 - 3 } & Lhitung & Ltabel & \\
\hline Eksperimen & 0,1246 & 0,1401 & Normal \\
\hline Kontrol & 0,0888 & 0,1401 & Normal \\
\hline
\end{tabular}

Berdasarkan Tabel 1 diperoleh bahwa data postes kedua kelas berdistribusi normal. Pengujian hipotesis dilakukan dengan uji F. Hasil Uji homogenitas data yang diperoleh dapat dilihat pada Tabel 5 .

Tabel 5. Ringkasan Hasil Uji Homogenitas Data Pretes

\begin{tabular}{|l|l|l|l|l|}
\hline Data & Varians & $\mathbf{F}_{\text {hitung }}$ & $\mathbf{F}_{\text {tabel }}$ & Kesimpulan \\
\hline Eksperimen & 105,1 & 1,58 & 1,705 & Homogen \\
\hline Kontrol & 166,1 & 1,58 & \multirow{4}{|l}{} \\
\hline
\end{tabular}

Berdasarkan Tabel 5 nilai $F_{\text {hitung }}$ $<\mathrm{F}_{\text {tabel }}$ yang berarti bahwa sampel yang digunakan dalam penelitian ini dinyatakan homogen atau dapat mewakili seluruh populasi yang ada. Hasil pengujian hipotesis dapat dilihat pada Tabel 6 .

Tabel 6. Ringkasan perhitungan

Uji t

\begin{tabular}{|l|c|c|c|l|}
\hline \multicolumn{1}{|c|}{ Data } & $\begin{array}{c}\text { Rata }^{-} \\
\text {rata }\end{array}$ & thitung & t $_{\text {tabel }}$ & Kesimpulan \\
\hline Eksperimen & 73,6 & \multirow{2}{*}{4,91} & 1,705 & $\begin{array}{l}\text { Ada } \\
\text { perbedaan } \\
\text { yang } \\
\text { signifikan }\end{array}$ \\
\hline Kontrol & 60,8 & 4,9 & &
\end{tabular}

Berdasarkan Tabel 6 dapat disimpulakan bahwa hasil belajar siswa pada kelas eksperimen lebih besar dari hasil belajar kelas kontrol, berarti ada perbedaan hasil belajar dengan menggunakan model pembelajaran berdasarkan masalah di kelas X Semester I SMA Swasta Budi Agung Medan T.P 2014/2015.

Aktivitas belajar siswa dapat dilihat pada Tabel 7.

\section{Tabel 7. Aktivitas Belajar Siswa}

\begin{tabular}{|l|l|c|l|l|}
\hline \multicolumn{2}{|c|}{ Sampel } & $\begin{array}{c}\text { Jumlah } \\
\text { Skor } \\
\text { Rata- } \\
\text { Rata }\end{array}$ & $\begin{array}{c}\text { Nilai } \\
\text { Akhir }\end{array}$ & $\begin{array}{c}\text { Rata- } \\
\text { Rata }\end{array}$ \\
\hline $\begin{array}{l}\text { Kelas } \\
\begin{array}{l}\text { Eksper } \\
\text { imen }\end{array}\end{array}$ & Pertemuan I & 14,35 & 68,32 & 73,13 \\
\cline { 2 - 4 } & Pertemuan II & 14,93 & 71,09 & \\
\cline { 2 - 4 } & Pertemuan III & 16,80 & 80 & \\
\hline
\end{tabular}

\section{Pembahasan}

Penelitian ini diawali dengan memberikan pretes terhadap kedua kelas sampel dengan jumlah soal 20 dalam bentuk pilihan berganda dengan 5 opsi yaitu pada jkelas eksperimen dan kelas kontrol. Hasil pretes kelas Eksperimen (P) memperoleh nilai rata-rata 52,5 dan nilai rata-rata kelas kontrol (Q) adalah 53,3. Hasil tersebut menyatakan bahwa kemampuan awal siswa pada kelas eksperimen sama 
dengan kemampuan awal kelas kontrol sebelum diberi perlakuan. Setelah diberi perlakuan yang berbeda yaitu pada kelas eksperimen menggunakan model pembelajaran berdasarkan masalah sedangkan pada kelas kontrol menggunakan model pembelajaran konvensional. Setelah diberikan perlakuan kedua kelas diberikan tes akhir (postes) untuk melihat adanya perbedan akibat diberikan perlakuan pembelajaran yang berbeda.Hal ini dapat dilihat dari hasil rata-rata postes di kelas $\mathrm{P}$ sebagai kelas eksperimen memperoleh nilai ratarata 73,6 , sedangkan nilai rata-rata postes dikelas Q sebagai kelas kontrol 60,8 . Hasil uji hipotesis untuk postes menggunakan uji t dua pihak pada taraf $\alpha=0,05$ diperoleh bawha ada perbedaan hasil belajar siswa yang menggunakan model pembelajaran berdasarkan masalah dengan model pembelajaran konvensional dan dapat disimpuulkan bahwa model pembelajaran berdasarkan masalah memiliki kelebihan dari nilaipostes yang meningkat.

Model

berdasarkan memberikan kesempatan pada siswa bereksplorasi memecahkan tugas yang diberikan dan bekerja sama dengan siswa, sehingga siswa mampu memanfaatkan waktu dan menunjukkan minat terhadap bermacam-macam masalah yang ada disekitarnya. Siswa dalam hal ini aktif dan antusias untuk bekerja sama dengan teman satu kelompok dalammenyelesaikan masalah yang diberikan oleh peneliti. Siswa juga tertarik dan aktif saat melaksanakan eksperimen dan menggunakan pendapat yang berbeda saat diadakan penyajian hasil antar kelompok.
Adapun beberapa kelebihan dari pembelajaran berdasarka masalah adalah :

1. Meningkatkan motivasi belajar siswa karena siswa dilibatkan secara aktif dalamproses pembelajaran.

2. Siswa dilatih untuk bekerjasama dan berbagi pengetahuan dengan siswa lain.

3. Siswa lebih mengaitkan pembelajaran dengan kehidupan sehari-harinya serta lebih aktif memberi umpan balik pada saat melaksanakan presentasi.

\section{KESIMPULAN DAN SARAN Kesimpulan}

Berdasarkan hasil analisis data, dapat disimpulkan bahwa ada pengaruh penggunaan model pembelajaran berbasis masalah untuk terhadap hasil belajar siswa pada materi pokok besaran dan satuan di kelas X.

\section{Saran}

Berdasarkan hasil pembahasan penelitian yang dikemukakan maka untuk tindak lanjut penelitian ini, peneliti mempunyai beberapa saran diantaranya adalah bagi para peneliti selanjutnya sebaiknya benar-benar mengefesiensikan waktu dalam menerapkan ke enamlangkah pembelajarannya dengan rencana pembelajaran yang dibuat. Bagi para peneliti selanjutnya diharapkan tetap menggunakan media yang menarik agar dapat meningkatkan minat dan motivasi belajar siswa. Bagi peneliti selanjutnya disarankan mengkolaborasikan media sederhana dengan video yangn mendukung dengan media yang diberikan kepada siswa. Bagi peneliti selanjutnya disarankan melakukan penelitian pada lokasi yang berbeda serta 
terlebih dahulu memperhatikan kelemehan-kelemahan dalam penelitian ini untuk memperoleh hasil belajar yang lebih baik.

\section{DAFTAR PUSTAKA}

Sudjana, (2005), Metoda Statistika.

Tarsito, Bandung. 